\title{
A River about to Die: Yamuna
}

\author{
Anil Kumar Misra \\ Department of Civil Engineering, Institute of Technology and Management, Gurgaon, India \\ E-mail: anilgeology@rediffmail.com \\ Received January 15, 2010; revised March 25, 2010; accepted April 2, 2010
}

\begin{abstract}
River Yamuna is one of the most polluted rivers of the India. It originates from Yamunotri glaciers in the lower Himalayas at an elevation of approximately 6387 meters. The barrages formed on the river are playing a major role in escalating the river pollution. River can be divided into five segments on the bases of hydrological and ecological conditions. Water quality of only one segment (Himalayan segment) meets the river water quality standards. Normally no water is allowed to flow downstream of the Himalayan segment (Tejewala barrage) especially in the summer and winter seasons to fulfill the demand of water of the surrounding area. Whatever water flows in the downstream of the Tajewala barrage is the untreated or partially treated domestic and Industrial wastewater contributed through various drains. The discharge of untreated domestic and industrial effluents have severely affected the quality of Yamuna River and now it falls under the category E, which makes it fit only for recreation and industrial cooling, completely ruling out the possibility for underwater life and domestic supply. Almost every year mass death of fishes is reported. Pollution levels in the Yamuna River have risen. Biochemical oxygen demand (BOD) load has increased by 2.5 times between 1980 and 2005: From 117 tonnes per day (TDP) in 1980 to 276 TDP in 2005. The Yamuna has been reduced to a small stream, draining industrial effluents, sewage, dirt and other toxic substances. There is an urgent need to take stringent measures to alleviate these pollution loads and save an ailing river.
\end{abstract}

Keywords: Yamuna River, Himalayan Segment, Delhi Segment, Dissolved Oxygen, BOD, COD, Organic Matter, River Water Quality, India

\section{Introduction}

River Yamuna is the largest tributary of the Ganga River in North India. Its total length is around 1370 kilometers. Yamuna originates from the Yamunotri Glacier of Uttar Kashi in Uttar Pradesh. River Tons and Giri are the important tributaries of Yamuna and principle source of water in mountainous ranges. Yamuna flows through the states of Delhi, Haryana and Uttar Pradesh, before merging with the Ganges at Allahabad. World famous cities like Delhi, Mathura and Agra lie on its banks. On the basis of hydrological and ecological conditions Yamuna has been classified into five segments that are Himalayan Segment, Upper Segment, Delhi Segment, Eutriphicated Segment and Diluted Segment [1]. Table 1 and Figure 1 show the area covered under these segments, while Table 2 shows the state wise land use pattern of the catchment area of river Yamuna. After origin Yamuna river flows through several valleys for about $200 \mathrm{~km}$ in lower Himalayas and emerges into Indo-Gangetic Plains. In the Himalayan Segment (from
Yamunotri Glacier to Tajewala Barrage) the river water quality is good and it meets all the standards also. Within this segment in Hathnikund/Tajewala in Yamuna Nagar district of Haryana state, river water is diverted into Eastern Ya-muna Canal (EYC) and Western Yamuna Canal (WYC). Generally no water is allowed to flow in the down-stream of the Taje-wala Barrage especially during summers and winters to fulfill the water demand of

Table 1. Different segments of the river Yamuna [1].

\begin{tabular}{ccc}
\hline River Segments & Segment Area & $\begin{array}{c}\text { Approx. Segment } \\
\text { Length }\end{array}$ \\
\hline Himalayan Segment & $\begin{array}{c}\text { From origin to } \\
\text { Tajewala Barrage } \\
\text { Tajewala Barrage to Wa- } \\
\text { zirabad Barrage }\end{array}$ & $172 \mathrm{~km}$ \\
Delhi Segment & $\begin{array}{c}\text { Wazirabad Barrage to } \\
\text { Okhla Barrage }\end{array}$ & $224 \mathrm{~km}$ \\
Eutriphicated Segment & $\begin{array}{c}\text { Okhla Barrage to Chambal } \\
\text { Confluence }\end{array}$ & $490 \mathrm{~km}$ \\
Diluted Segment & $\begin{array}{c}\text { Chambal Confluence to } \\
\text { Ganga Confluence }\end{array}$ & $468 \mathrm{~km}$ \\
\hline & \multicolumn{2}{c}{} \\
\hline
\end{tabular}




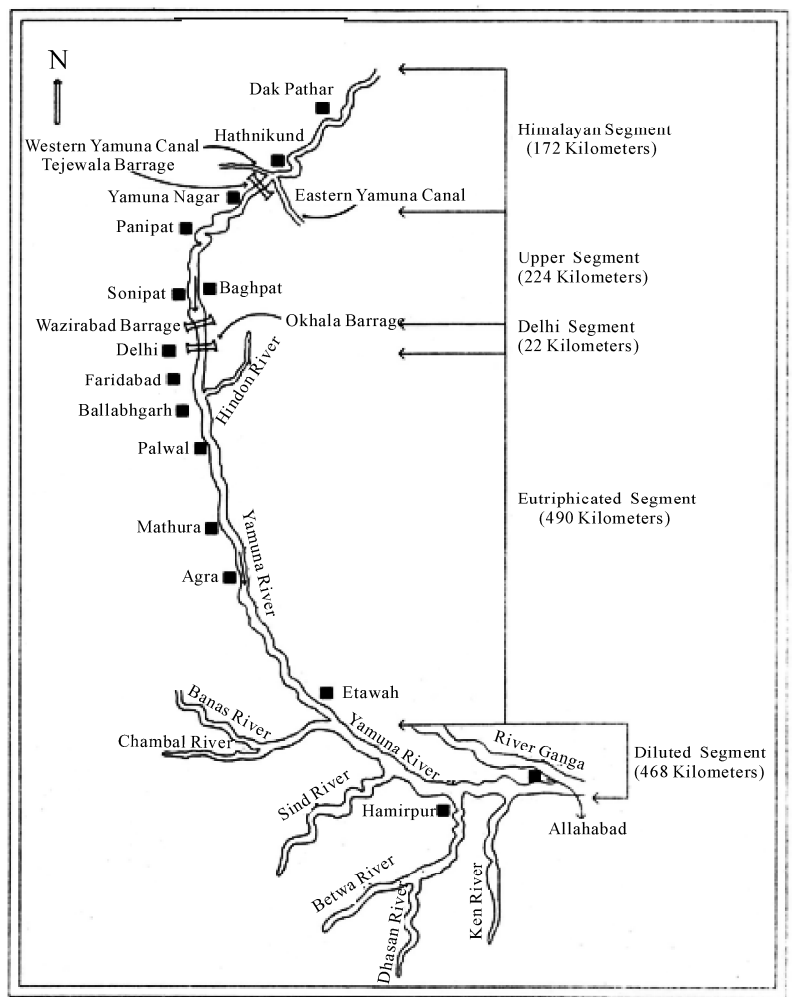

Figure 1. Shows the different segments of river Yamuna.

the surrounding districts. Due to this the river remains dry in many areas between Tajewala and Delhi. Whatever water flows between Tajewala Barrage and Delhi of the river is the untreated or partially treated domestic and industrial effluents discharge by several drains. After crossing a route of $224 \mathrm{~km}$ of upper segment Yamuna enters Delhi. The Yamuna water is again trapped by Wazirabad barrage for the domestic supply of water to
Delhi. Usually no water or extremely little water is allowed to flow downstream of this barrage during lean seasons. There is another barrage Okhla barrage $22 \mathrm{~km}$ downstream of Wazirabad barrage this segment is called Delhi segment and it receives water from seventeen sewage drains of Delhi, Najafgarh drain. It is considered as the most polluted segment of Yamuna River. From this segment Yamuna water is diverted into Agra canal for irrigation. River water is not allowed to flow downstream during summers; beyond the Okhla barrage whatever water flow in Yamuna River is the domestic and industrial wastewater generated from east Delhi, Noida and Sahibabad and joins the river through Shahdara drain. At the upstream of Mathura Gokul barrage is also decreasing the flow and thereby polluting the river. Yamuna river after receiving water through other important tributaries joins the river Ganga and the underground Saraswati at Prayag (Allahabad) after traversing about $950 \mathrm{~km} \mathrm{[1].}$

Yamuna River passing through $22 \mathrm{~km}$ in Delhi was once described as the lifeline of the city, but today it has become one of the dirtiest rivers in the country. According to the Central Pollution Control Board (CPCB) the water quality of Yamuna River falls under the category "E" which makes it fit only for recreation and industrial cooling, completely ruling out the possibility for underwater life [2]. The pollution of the Yamuna River from domestic discharges from Delhi, Ghaziabad, Noida, Faridabad, Mathura and Agra has rendered the river unfit for any use. Yamuna's water quality in the Himalayan segment and in the segment after confluence with the Chambal river is relatively good [3-5]. In Delhi around 3296 MLD (million litres per day) of sewage by virtue of drains out falling in Yamuna and approximately 3.5 lakh people live in the 62000 Jhuggis that have come up on the Yamuna river bed and its embankment [6]. Because of the

Table 2. State wise land use pattern of river Yamuna catchment area (source: comprehensive plan of flood control for ganga sub-basin and tributary river system, ganga flood control committee, ministry of water resources, government of India).

\begin{tabular}{|c|c|c|c|c|c|c|}
\hline \multirow{2}{*}{ State } & \multirow{2}{*}{$\begin{array}{c}\text { Area }(\% \text { of } \\
\text { total } \\
\text { catchment })\end{array}$} & \multicolumn{3}{|c|}{ Land use pattern } & \multirow{2}{*}{$\begin{array}{c}\text { Land } \\
\text { actually } \\
\text { cultivated \% }\end{array}$} & \multirow{2}{*}{$\begin{array}{c}\text { Land under } \\
\text { habitational } \\
\text { use } \%\end{array}$} \\
\hline & & $\begin{array}{l}\text { Non-arable } \\
\text { land } \%\end{array}$ & $\begin{array}{c}\text { Forest Land } \\
\%\end{array}$ & $\begin{array}{c}\text { Cultivable } \\
\text { Land \% }\end{array}$ & & \\
\hline Himachal Pradesh & 1.6 & 25.0 & 59.4 & 15.6 & 14.2 & 1.5 \\
\hline Haryana & 6.1 & 18.1 & 2.4 & 79.5 & 59.9 & 3.6 \\
\hline NCT-Delhi & 0.4 & 51.0 & 1.0 & 48.0 & 46.5 & 43.7 \\
\hline Uttaranchal & 1.1 & 5.0 & 22.0 & 23.0 & 14.3 & 1.6 \\
\hline Uttar Pradesh & 20.4 & 14.5 & 3.9 & 81.1 & 68.0 & 5.1 \\
\hline Rajasthan & 29.8 & 40.8 & 8.8 & 50.4 & 43.9 & 2.2 \\
\hline Madhya Pradesh & 40.6 & 26.0 & 18.0 & 56 & 50.7 & 1.8 \\
\hline Total & 100.0 & 27.5 & 12.5 & 60.0 & 51.9 & 2.9 \\
\hline
\end{tabular}


low flow (due to different barrages) and huge quantity of waste it receives the Yamuna river within the limits of the city have been given the dubious distinction of being one of the worst polluted rivers of the country by the Central Pollution Control Board (CPCB). According to the latest status of water quality in India (2007) released by CPCB the Yamuna water quality at Okhla and Nizamudin bridges has been described as the worst affected. As per data on water quality of water bodies and groundwater locations; it was placed seventh on the list of rivers with highest Biochemical Oxygen Demand (BOD), one of the most important indicators of pollution. The total biochemical oxygen demand content in the Yamuna was $93 \mathrm{mg} / \mathrm{L}$, while the permissible level is $3 \mathrm{mg} / \mathrm{L}$. The CPCB report says that the level of Dissolved Oxygen throughout the year in Yamuna was less than $4 \mathrm{mg} / \mathrm{L}$ and it was $0.0 \mathrm{mg} / \mathrm{L}$ at few locations down-stream of urban settlements due to discharge of untreated and partially treated wastewater. The water quality of Yamuna has deteriorated at Paonta Sahib, Kalanaur, Sonepat, Palla, Nizammudin, Okhla, Mazawali, Mathura, Agra, Bateshwar, Etawah, Juhika and Allahabad the western Yamuna canal downstream of Yamuna Nagar at Damla is " grossly polluted due to municipal and industrial waste water disposal".

The Yamuna is widely worshipped by devotees in India. A few centuries ago it prompted the Mughals to build one of their most magnificent monuments; the Taj Mahal on its bank; but today it has been reduced to a pale and stinking drain. About 57 million people depend on Yamuna River water. With an annual flow of about 10,000 cubic metres (cum) and usage of 4,400 cum (of which irrigation constitutes 96 percent), the river accounts for more than 70 percent of Delhi's water supplies. Available water treatment facilities are not capable of removing the pesticide traces. Waterworks laboratories cannot even detect them. Worse, Yamuna leaves Delhi as a sewer, laden with the city's biological and chemical wastes. Downstream, at Mathura and Agra, this becomes the main municipal drinking water source. Here, too, existing treatment facilities are not capable of detecting pollutants contained by river water. Thus, consumers in Mathura and Agra ingest unknown amounts of toxic pesticide residues each time they drink water. In Agra and Matura districts, the domestic and industrial users produce large quantities of waste products and the waterways provide a cheap and effective way of disposing them. Apart from that, water is discharged in Yamuna from Gokul barrage and Keetham Lake, $28 \mathrm{~km}$ upstream from Agra. Mathura refinery lifts raw water directly from Mathura canal, which acts as a feeder source for Keetham Lake. The water, which is released from the refinery, also seems to pollute Yamuna. During dry weather, the flow of Yamuna River consists almost en- tirely of effluents. The degree of pollution of Yamuna can be assed from an incident recounted below.

On $13^{\text {th }}$ June 2002 , thousands of dead and dying fishes were found strewn over the Sikendra Taj Mahal area along the water body. Reports of more fish deaths poured in from Bateshwar, about $78 \mathrm{~km}$ from Poiya Ghat in Agra (Figure 2). Such incidents are common; almost every year mass death of fishes is reported in Yamuna River [7]. Approximately 75 percent of precipitation in Yamuna basin occurs during the four monsoon months of June, July, August and September. This affects the river flow as well as the river water quality up to some extent.

The demand of fresh water has been continuously increasing with growing population and increase in agricultural and industrial activities. Majority of the demand of water of Delhi, Haryana, Uttar Pradesh and Madhya Pradesh states is met by Yamuna, which has already become a sewerage drain. This paper aims to discuss the most prominent reasons of Yamuna river pollution and easily feasible and economically feasible measures to prevent further pollution and improve the river water quality.

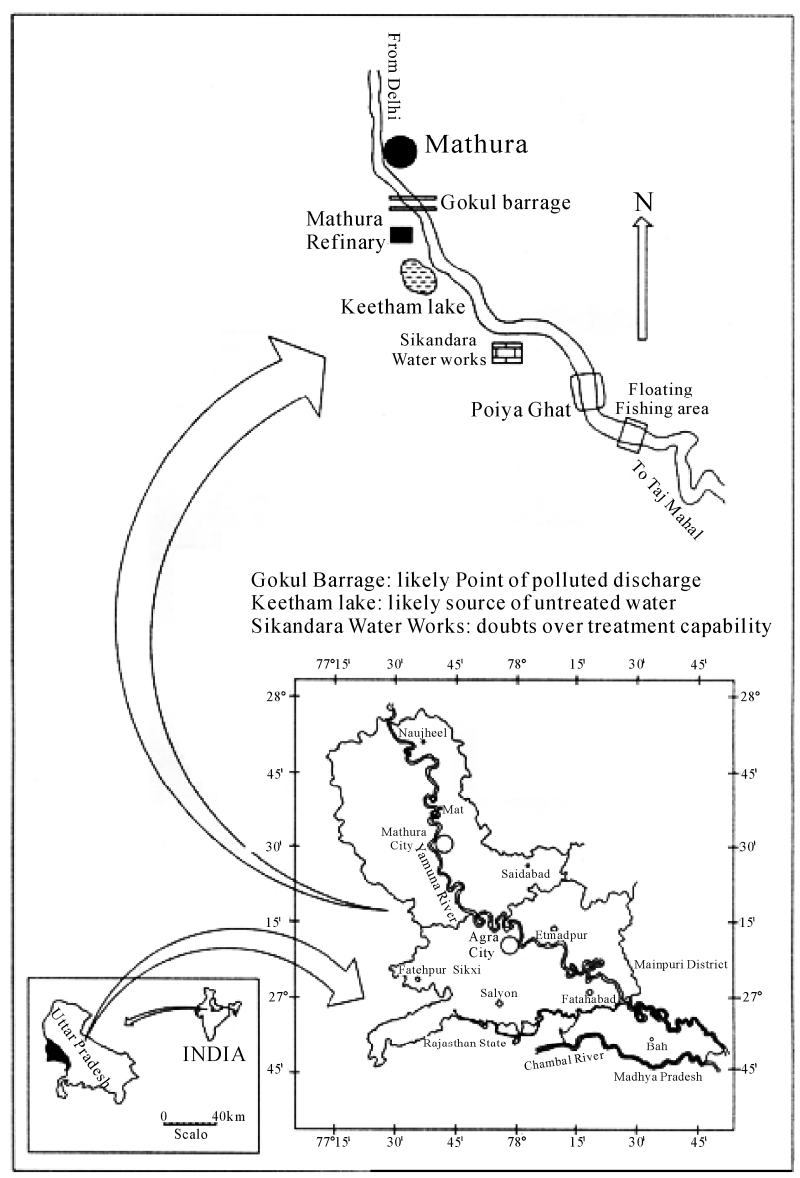

Figure 2. Shows the sites of maximum pollution and mass death of fishes reported in Agra and Mathura districts [7]. 


\section{Yamuna Water Quality Status}

\subsection{Yamuna Water Quality Status at Different Locations}

River water quality can be assessed by the analysis of nutrients, chemistry, and biology. The criteria for a healthy river are that it should contain at least $5 \mathrm{mg} / \mathrm{L}$ of Dissolved Oxygen (vital for the survival of marine life) and about $3 \mathrm{mg} / \mathrm{L}$ of Biochemical Oxygen Demand. Further the Pathogens (disease causing bacteria's) represented by the Faecal Coliforms counts should not exceed 500 per $100 \mathrm{~mL}$ of water. India River water qualities have been categories in five classes (http:// edugreen.teri.res.in/explore/maps/water.htm) that are Class A: The River water is fit for drinking after proper disinfection with the addition of chlorine or bleaching powder. Class B: Under this category the river water is fit only for bathing. Class C: The River water is fit for drinking only after proper treatment (screening to remove physical matters or particulate such as paper, plastic, etc. Class D: Under this class the river water is fit only for fish and wildlife and Class $\mathbf{E}$ : River water is suitable only for industrial cooling, irrigation, etc. Yamuna River belongs to class E [2].

Since 1975, there had been rapid urbanization, Industrialization and agricultural development in Yamuna basin, which have directly or indirectly affected the Yamuna water quality. Yamuna water quality is also affected by the six barrages in the river. Table 3 shows the diversion of Yamuna Water at various places all along its length. These barrages blocked the flow of the river and formed the lotic (flowing) environment. Generally most of the sludge get deposited at upstream of the barrages. This settled polluted materials moves to downstream along with sudden release of water from the barrages and increases the river pollution.

Water quality monitoring and analysis of Yamuna River is regularly carried out by Central Pollution Control Board (CPCB) since 1977. As per the report of
CPCB, 2006 different water quality parameters of Yamuna river are as follows.

\subsection{Biological Oxygen Demand (BOD)}

It measures the rate of oxygen used by biological organisms in the water body to decompose the organic matter polluted by sewerage or industrial effluents. High demand of BOD indicates that the level of dissolved oxygen is falling, and river's marine life and biodiversity is in danger. It is caused by the presence of high level of organic pollutants and nitrate in water body. The BOD level in Yamuna from Yamunotri (origin) to Palla (Place between Sonipat and Nizamuddin Bridge) in Delhi is usually ranges from 1 to $3 \mathrm{mg} / \mathrm{L}$. Up to Palla Yamuna is full of marine life, but beyond that wastewater drains outfall in Yamuna started. From Nizamuddin Bridge to Agra downstream the BOD level ranges from 3 to $51 \mathrm{mg} / \mathrm{L}$. The BOD level was also found above the permissible limits in Mathura, Agra, Etawah and Juhika. Figure 3 shows the average BOD levels in Yamuna River at different locations.

\subsection{Chemical Oxygen Demand (COD)}

COD beyond the permissible limit is the indicator of the organic and inorganic pollutants in the water body. The COD level in Yamuna ranges from 1 to $50 \mathrm{mg} / \mathrm{L}$ from its origin to Palla. Beyond Palla Yamuna River starts receiving large amount of wastewaters from different drain within Delhi and many downstream locations. The COD level start increasing from Nizamuddin Bridge and found above the permissible limits (ranges from 3 to $155 \mathrm{mg} / \mathrm{L}$ ) up to Juhika.

\subsection{Dissolved Oxygen (DO)}

DO level in Yamuna from its origin to Palla is found normal, but beyond that it started decreasing. After Wazirabad the DO level starts decreasing drastically and

Table 3. Diversion of Yamuna River water ([8] EYC (eastern Yamuna canal) WYC (western Yamuna canal).

\begin{tabular}{|c|c|c|c|c|}
\hline Site & Structure & State & Purpose & State of River \\
\hline Dak Patthar & Barrage & Uttranchal & Power Generation & Water diverted into canal \\
\hline Asan & Barrage & Uttranchal & Power Generation & Water diverted into canal \\
\hline Hathnikund & Barrage & Uttar Pradesh/Haryana & Irrigation and drinking water & $\begin{array}{l}\text { Water diverted into WYC and } \\
\text { EYC (No water flow down- } \\
\text { stream in dry season) }\end{array}$ \\
\hline Wazirabad & Barrage & Delhi & Drinking water & $\begin{array}{l}\text { Generally no water flow } \\
\text { downstream in dry season }\end{array}$ \\
\hline ITO bridge & Barrage & Delhi & Water supply to power plant & $\begin{array}{c}\text { Water available mainly from } \\
\text { drains }\end{array}$ \\
\hline Okhla & Barrage & Delhi/Uttar Pradesh & Water supply into Agra canal & $\begin{array}{l}\text { Generally no water flow } \\
\text { downstream in dry season }\end{array}$ \\
\hline
\end{tabular}




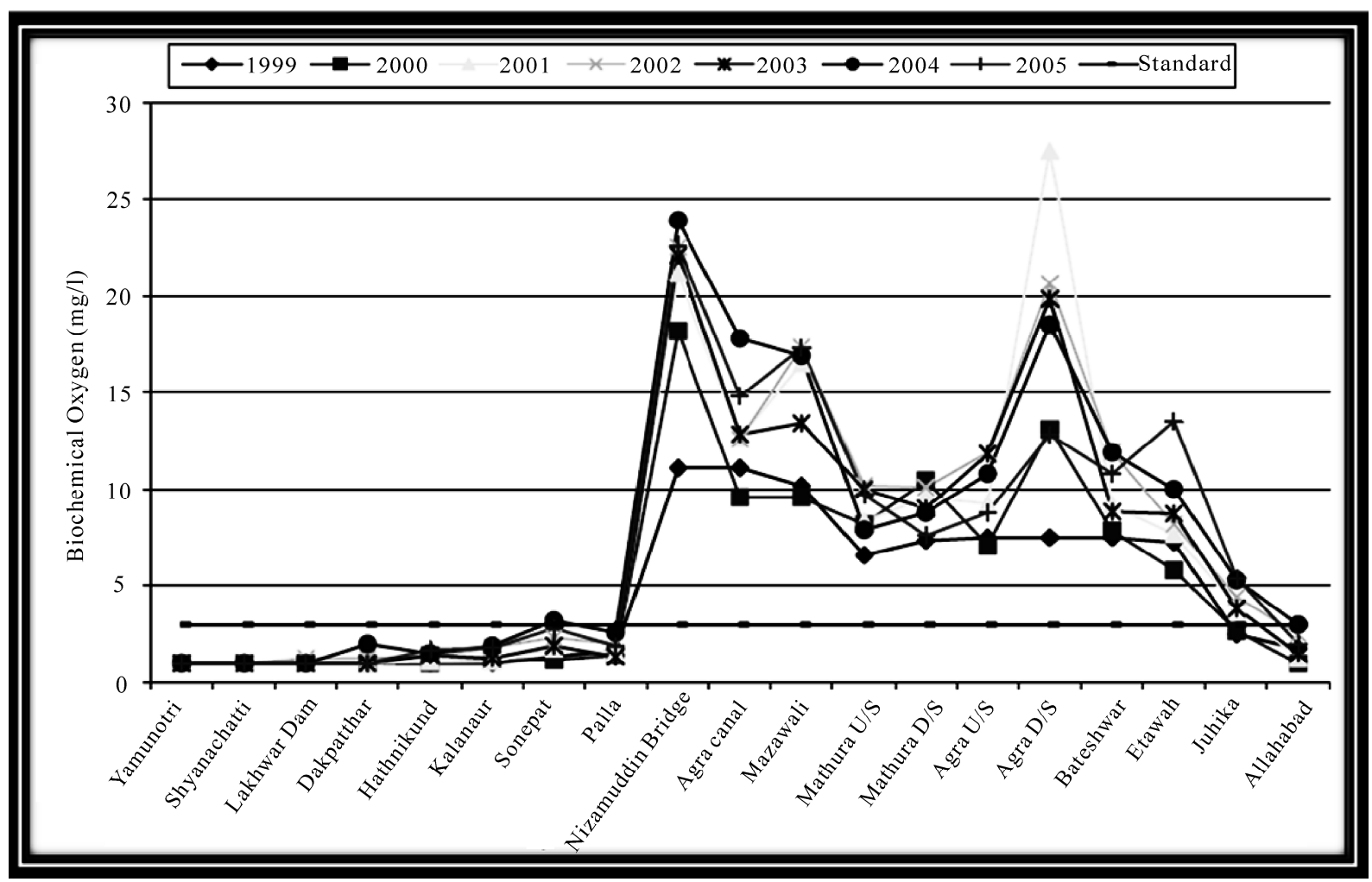

Figure 3. Average dissolved oxygen in Yamuna River [9].

majority of times the DO level was found nil at Delhi downstream locations; it may be attributed to Shahdara drain and Hindon River which discharge wastewater at these locations. Further the DO levels at locations in Mathura, Agra, Etawah and Juhika were found beyond the permissible limits. Figure 4 shows the average DO levels in Yamuna River at different locations.

The ammonia values in the entire Yamuna stretch were found varying from nil to $44 \mathrm{mg} / \mathrm{L}$ in 1999 to 2005 . Study of heavy metals at Palla and some of the impact locations such as Nizamuddin Bridge, Agra Canal, Mathura downstream and Agra downstream shows the presence of Cadmium, Nickel, Iron, Zinc and Chromium in Yamuna River. The maximum concentration of chromium $7.91 \mathrm{mg} / \mathrm{L}$ was found in January 2001, at Agra downstream, while the maximum concentration of Iron and Zinc was found $78.3 \mathrm{mg} / \mathrm{L}$ (Nizamuddin Bridge) and $1.37 \mathrm{mg} / \mathrm{L}$ (Palla) in July 2001 and June 2003 respectively. Apart from the heavy metals the presence of pesticides in Yamuna is also common. The pesticides like BHC (benzene hexa chloride), Dieldrin, Aldrin, Endosulfan and DDT were found in Yamuna river water at various locations. The maximum concentration of $\mathrm{BHC}$ $(5517.79 \mu \mathrm{g} / \mathrm{L})$ was observed at Agra downstream in September 2005. Whereas the maximum concentration of Aldrin (213.41 $\mu \mathrm{g} / \mathrm{L}$, December 2001), Dieldrin $(50.85 \mu \mathrm{g} / \mathrm{L}$, March 2005) and Endosulfan $(4591.08 \mu \mathrm{g} / \mathrm{L}$, June 2002) was observed at Nizamuddin bridge and
Mathura downstream respectively [9]. The sources of pesticides in the Yamuna seem to be agriculture activities common in the river catchment area as well as also along the bank of the river.

Almost every year mass death of fishes is reported from these locations and right now the situation is that rarely the existence of fishes is reported in Yamuna River between Delhi to Agra. The water quality status of some of the important parameters is shown in Tables 4 and 5 .

\section{Different Sources of Pollution in the Yamuna River}

Approximately 75 percent of urban waste in India ends up in the country's rivers, and unchecked urban growth across the country combined with poor government oversight means the problem is only getting worse. This situation has arisen despite the huge investments made by subsequent governments in cleaning them up. As a result, our survival and that of rivers is at stake. According to the Centre for Science and Environment, approximately 75 to 80 percent of the river's pollution is the result of raw sewage, industrial runoff and the garbage thrown into the river and it totals over 3 billion liters of waste per day. About 20 billion rupees, or almost US $\$ 500$ million, has been spent on various cleanup efforts. 


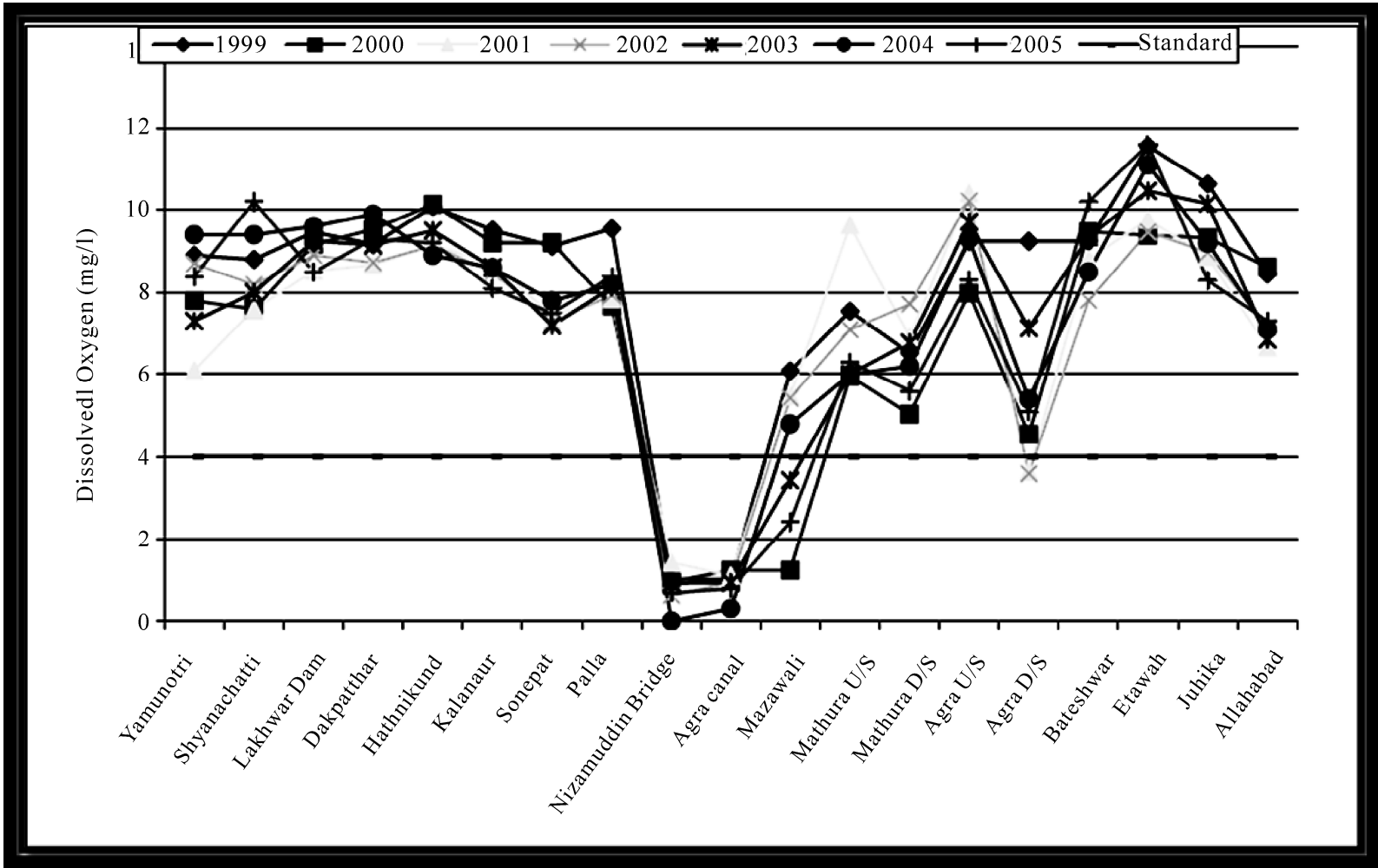

Figure 4. Average biochemical oxygen in Yamuna River [9].

Table 4. Water quality ranges of some of the parameters in Yamuna River [9].

\begin{tabular}{|c|c|c|c|c|c|c|c|}
\hline \multirow{2}{*}{$\begin{array}{l}\text { S. } \\
\text { No. }\end{array}$} & \multirow{2}{*}{ Parameters } & \multicolumn{3}{|c|}{ Minimum } & \multicolumn{3}{|c|}{ Maximum } \\
\hline & & $\begin{array}{l}\text { Value } \\
(\mathrm{mg} / \mathrm{L})\end{array}$ & Location & Year & $\begin{array}{l}\text { Value } \\
(\mathrm{mg} / \mathrm{L})\end{array}$ & Location & Year \\
\hline 1 & TDS & 83 & Hathnikund & 2000 & 1357 & Etawah & 2000 \\
\hline 2 & Chloride & 2 & $\begin{array}{c}\text { Hathnikund, } \\
\text { Sonepat, Kalanaur }\end{array}$ & 2001 & 424 & Agra d/s (1/2) & 2005 \\
\hline 3 & Sulphate & 7 & Etawah & 2005 & 217 & Nizamuddin bridge & 1999 \\
\hline 4 & Sodium & 6 & $\begin{array}{l}\text { Hathnikund, } \\
\text { Sonepat }\end{array}$ & $\begin{array}{l}2001,2003, \\
2004\end{array}$ & 406 & Agra d/s (1/4) & 2004 \\
\hline 5 & Calcium & 7 & Kalanapur & 2001 & 291 & Agra d/s (1/2) & 2005 \\
\hline 6 & Magnesium & 0.4 & Sonepat & 2004 & 77 & Agra canal (1/2) & 2004 \\
\hline 7 & Total hardness & 46 & Hathnikund & 2005 & 792 & Agra $\mathrm{u} / \mathrm{s}$ & 2005 \\
\hline 8 & Alkalinity & 40 & Hathnikund & 2000 & 425 & Mazawali & $\begin{array}{l}2004 \\
2005\end{array}$ \\
\hline 9 & Phosphate & 0.02 & Palla & 2005 & 2.00 & Mathura u/s & 2004 \\
\hline 10 & Potassium & 1.0 & Hathnikund & 2000 & 48 & Agra D/s & 1999 \\
\hline
\end{tabular}

The pollution in the Yamuna River is continuously escalating and the river water is unfit for any use. There are serious water quality problems in the, cities, towns and villages using Yamuna rivers as a source of their water and the Yamuna is under serious threat from unprecedented escalation in urbanization and industrialization.
The major sources of pollution in Yamuna river are:-

\subsection{Industrial Effluents}

Yamuna River is also called mailee (dirty) river and river of sorrow to Delhi, Mathura and Agra. The River water 
Table 5. Scenario of water quality status of Yamuna River [10].

\begin{tabular}{|c|c|c|c|}
\hline Sewage Generated & Total Sewage & Sewage Treated & Remarks \\
\hline Daily Sewage Generated in Delhi & 2871 million litres & 1478 litres & $\begin{array}{c}\text { Remaining sewage goes } \\
\text { into the Yamuna } \\
\text { through the } 17 \text { drain }\end{array}$ \\
\hline TDS & Quantity & Permissible Limits & Remarks \\
\hline Content of Suspended Solids in Yamuna & $1000-10,000 \mathrm{mg} / \mathrm{L}$ & $100 \mathrm{mg} / \mathrm{L}$ & \\
\hline BOD & Quantity & Permissible Limits & Remarks \\
\hline Biochemical Oxygen Demand (BOD) & $15-30 \mathrm{mg} / \mathrm{L}$ & $3 \mathrm{mg} / \mathrm{L}$ & \\
\hline Coliform Level & Quantity & Permissible Limits & Remarks \\
\hline Coliform Level in Yamuna & $\begin{array}{l}\text { 11.8 Crore per } 100 \mathrm{ml} \text { of } \\
\text { water }\end{array}$ & $\begin{array}{l}5000 \text { per } 100 \mathrm{ml} \text { of } \\
\text { water }\end{array}$ & $\begin{array}{l}\text { Coliforms causes many } \\
\text { serious disesses relating } \\
\text { to the digestive system }\end{array}$ \\
\hline Dissolved Oxygen & Quantity & Normal Oxygen Level & Remarks \\
\hline Dissolved Oxygen Level & $0 \mathrm{mg} / \mathrm{L}$ & $4 \mathrm{mg} / \mathrm{L}$ & $\begin{array}{c}\text { The dissolved oxygen } \\
\text { level is critically impor- } \\
\text { tant for water plants and } \\
\text { fish }\end{array}$ \\
\hline Requirement of Drinking Water & Total Requirement & $\begin{array}{l}\text { Available Drinking } \\
\text { Water }\end{array}$ & Remarks \\
\hline Delhi's Drinking Water Requirement & 1480 cusecs & 1221 cusecs & \\
\hline Forest Cover & Existing Forest Cover & Required Forest Cover & Remark \\
\hline Delhi's Forest Cover & $10.2 \%$ of total area & $33 \%$ of the total area & \\
\hline Air Pollution & \multicolumn{3}{|c|}{$\begin{array}{c}\text { RSPM levels } 3 \text { times higher than normal, CO levels are twice the permissible } \\
\text { standards }\end{array}$} \\
\hline
\end{tabular}

is extremely black, it appears like an industrial drain in Delhi, as majority of the industries are on its bank and used to dump the untreated effluents into the river. The water in the Yamuna remains stagnant for approximately nine months in a year. There are unlimited numbers of industrial units, draining immense amount of untreated water in Yamuna existing in Delhi, Faridabad, Mathura and Agra. Central Pollution Control Board (CPCB) had estimated that there were approximately 359 industrial units, which directly or indirectly discharge their effluents in Yamuna. A report of CPCB [8] indicates that there were about 42 industrial units in Delhi directly polluting the Yamuna.

\subsection{Domestic Waste Water}

Yamuna is considered one of the most polluted rivers of the world especially around the Delhi, because of the large amount of the wastewater discharge. According to a Central Pollution Control Board (CPCB) survey, Delhi contributes 23 percent of the total wastewater generated by Class I cities (cities with more than 100,000 people). More shockingly, this is 47 per cent of the waste generated by 101 Class I cities and 122 Class II cities (Population: 50,000-99,999) in the Ganga basin. The untreated domestic wastewater is dumped in the Yamuna, which has ammonia in it, increases its concentration. The water becomes untreatable when the ammonia concentration reaches to $0.4 \mathrm{mg} / \mathrm{L}$ or more. In Delhi often ammonia in Yamuna River has been found more than $0.4 \mathrm{mg} / \mathrm{L}$ especially during summer. The river has turned grossly polluted due to continuous discharge of domestic wastewater from Palla to Etawah.

\subsection{Pollution from Agriculture}

The agriculture is also one of the main sources of contamination in the Yamuna River, which directly or indirectly affects river water quality through, ground and surface water runoff of agricultural land through monsoon and non-monsoon precipitation and seepage of irrigation water, which is composed of artificial fertilizer residues, insecticides, herbicides, pesticides and farmyard waste. Agriculture is very common in the catchment areas as well as all along the bank of the Yamuna River. Usually in the non-monsoon time majority of the river streams shrinks and their catchment areas are used for farming and thus directly contributing pesticides residue in the river.

\subsection{Solid Wastes}

Solid wastes are the unwanted and discarded products in the solid states, their proper management are necessary. 
Dumping of solid waste and garbage is one of the major problems in Yamuna River. As per the report of Yamuna Action Plan the content of suspended solids in Yamuna is $1000-10,000 \mathrm{mg} / \mathrm{L}$ and the permissible content of suspended solids is $100 \mathrm{mg} / \mathrm{L}$. The main reason behind this is the high density of the population living in the city and the dumping of untreated water and solid waste into the river. Solid waste are generally composed of human fecal matter, cow dung, generated from various authorized and unauthorized dairy colonies located in Sonepat, Panipat, Delhi, Noida, Mathura, Agra and Etawah are being discharged untreated into river Yamuna and are considered as one of the major non-point source of pollution.

\subsection{Other Sources}

There are many other reasons of pollution of Yamuna river water, such as on holy and religious occasions every year, thousands of peoples take a dip in the Yamuna and leave behind worship materials, polythene bags, clay idols, human excreta, account books and floral offerings in the river water, which increases the suspended materials in the water. The superstitious mindset of the peoples has contributed and still contributing and escalating the Yamuna River Pollution. Further large number of cities and small towns are located all along the Yamuna River. Majority of these small cities and towns do not have the sanitation facilities. Thus the most of the peoples uses river catchment areas for defecation, which causes pathogenic and organic contamination in the river. Peoples have the habit of dumping unburnt bodies of human beings and animals into the river. According to superstition, bodies of those who die from certain diseases (asthma, tuberculosis, leprosy, snake bite, poisoning etc.) and those of newborn babies, unmarried persons and holy men are consigned to the river. But poor people were also dumping bodies into the rivers to save on costly wood cremation.

\section{Policies and Strategies to Improve Yamuna Water Quality}

Majority of rivers of India are facing acute water pollution problems and river Yamuna is one of them. Due to excessive industrialization and urbanization of river Yamuna especially in Delhi, Mathura and Agra have now become a drain. The water pollution of the river has gained large heights. Now it is become imperative to, yield a plan identifying viable remedial options and strategies for the Yamuna River clean up. Efforts will be made to resort to a bottom-up approach rather than a top-down one to help this highly polluted river, which is the major life-supporting artery of Delhi, Mathura, Agra and Etawah and many other cities in India. To apply the strategies effectively, we need to develop awareness among masses, education, and improved watershed management that will improve the water quality of this holy river. Some of the important measures that can be very effective in improving Yamuna water quality status are as follows.

\subsection{Proper Management and Treatment of Wastewater}

Waste water discharges in rivers destroy marine lives; degrade the environment, and causes water shortage and waterborne diseases. Their proper management and treatment is necessary because it reduces or removes the organic matter, solids, nutrients, disease-causing organisms and other pollutants from the wastewater before it is discharged to river water. Delhi alone contributes around 3,296 MLD of sewage water in Yamuna River. Therefore it is imperative to take necessary action and promotes the following strategies.

\subsubsection{Conserve Water and Use It Effectively}

Now day's both urban and rural areas, are facing the problems of water shortage and majority of the urban areas are depend upon the river water for the domestic supplies. Due to severe pollution river water requires high grade treatment prior to use for domestic purposes, which is expensive and not easily feasible. Therefore the conservation of water is necessary. Usually the construc tion of houses, footpaths and roads has left little exposed earth for water infiltration and recharge of groundwater aquifers. In the rural and urban areas the floodwater quickly flows to the nallas (drain) and rivers, which then dry up soon after the rains stop. If this water can be held back, it can seep into the ground and recharge the groundwater bodies.

\subsubsection{Promote Wastewater Treatment \& Technologies} Works on the development of effective and easily feasible and economically feasible wastewater treatment techniques should be supported by the government. Encourage people in social gathering to reduce wastewater generation and use low cost and low maintenance wastewater treatment techniques at the common collection points.

\subsubsection{Drainage Water Management and Treatment}

The drainage water management relies on the natural rainfall. It can be done by forming water control structure in the main, sub main or lateral drain such as different kinds of check dams. These structures control the surface runoff and ensure the maximum infiltration of drainage water and recharge the water table. Apart from that within the drainage canal or drain route artificial filters based on grain size sedimentation can be formed they are very effective in water treatment. 


\subsubsection{Recycling and Reuse of Wastewater}

Now day's wastewater can be recycled through effective technologies and it can be reused for different purposes such as agricultural and landscape irrigation, industrial processes, toilet flushing, and recharge a ground water basin. Wastewater can be recycled and reused onsite; for example, an industrial can recycles water it used for cooling processes. Likewise the municipal wastewater and sewage water can also be recycled and can be used for industrial purposes.

\subsubsection{Financing Wastewater Management Schemes}

There are number of Government, semi-government, NGO's, private companies and environmental agencies are available which are working in the field of wastewater management. These organizations should be encouraged to work on the waste management techniques and can be financed through projects, schemes.

\subsubsection{Improving the Sewerage System}

The status of sewerage systems especially in the cities, towns and blocks all along the Yamuna River course is extremely bed, due to this large quantity of untreated or partially treated sewage water mixed with river water. Further many cities, small towns and blocks do not have the sewer system facilities. The existing sewer system improvement and formation are needed to reduce the risk of seepage of sewerage water and material into the groundwater and river, especially during rainy seasons.

\subsubsection{Upgrading of Sewage Treatment Plant}

The old, inadequate sewer systems are one of the major causes of water pollution in Yamuna. Now it's become imperative to upgrade all the existing sewerage treatment plants and increase their capacity. The areas without sewer system need immediate action as most of the wastewater and waste is directly dumped in river water or ground.

\subsubsection{Proper Disposal of Sewage}

Disposal of sewage effluents are big problems almost in every big city. It cannot be simply disposed off due to their microbiological and chemical characteristics. Only after full treatment they can be discharged into river. But alone in Delhi approximately 1393 million liters of untreated sewage is disposed in Yamuna. Even the partially treated sewage effluents are not fully suitable for the discharge in river. More sewerage treatment plants should be formed immediately to prevent the water pollution in Yamuna River and discharge of untreated sewage should be banned.

\subsection{Agricultural Practices Improvement}

Farmers are using large quantities of chemical fertilizer, insecticides, pesticides, to increase short term crop yields or keeping the soil productive, without knowing the exact quantities are required. It is estimated that about one half of every metric ton of fertilizer or pesticides applied to fields never even makes it into plant tissue, but instead ends up evaporating or being washed into local waterways. The excess amount of fertilizer use entered the soil, ground and surface water bodies and pollutes them and during rainy season by runoff it pollutes the lakes, ponds and rivers and causes eutrophication, which decreases the dissolved oxygen level and threatens animal and plant health. To prevent such situation emphasis should be given on the use of bio-fertilizers having least chemical constituents and accelerate the efforts to prevent the soil erosion through vegetation cover especially along the either side areas of river.

\subsection{Environmental Management}

River environmental management depend on interactions between river, environment and human infrastructure, including the interactions between ecology, hydrology, water quality, climate, flooding, public sanitary facilities, waste water inputs and waste water treatment facilities. Thus a river directly as well as indirectly reflects the environmental management system facilities of any town, city, state and country. To protect Yamuna River from the pollutants some of the important steps should be taken immediately such as.

\subsubsection{Solid Waste Management}

Almost all the cities situated on the either sides of Yamuna River have been experiencing very high population growth and urbanization. This has increased the urban environmental problems, such as solid waste management. Most of the cities do not have adequate solid waste management system and it causes heavy pollution to Yamuna River. Further the quantity of solid waste generated has increased significantly and its characteristics have changed as a result of the change in peoples' lifestyles due to swift urbanization. Every day the river is polluted by solid waste disposal, animal bathing, disposal of dead bodies, slums along the river and cattle wallowing.

Solid waste disposal of normal solid or semisolid materials, resulting from human and animal activities, that are useless, unwanted, or hazardous can be recycled and reused in daily lives. Once cleaned and separated, the recyclables solid wastes can be converted into products from total or partial recycled materials. Common household items, such as newspapers, paper towels, aluminum, plastic, and glass soft drink containers; steel cans; and plastic laundry detergent bottles can be formed from totally or partially recycled solid wastes. Further recycled materials can also be used in innovative 
applications such as recovered glass in roadway asphalt (glassphalt) or recovered plastic in carpeting, park benches, and pedestrian bridges. The cities like Sonepat, Panipat, Delhi, Noida Mathura, Agra and Etawah pro-duce large amount of solid waste and plays a major role in polluting the Yamuna. If more and more recycled plants are formed in these cities then problem related with solid waste disposal can be effectively controlled.

\subsubsection{Formation of Public Toilets}

Approximately 30 to $40 \%$ of urban population in major cities like Delhi, Agra, Mathura and Etawah stays in slums without sanitation facilities. People in these areas generally have the practice of open defecation and discharge of sewage in the Yamuna river catchment area due to this the water quality of the river is continuously deteriorating. Water contaminated with faecal matter causes diarrhoea (with proper sanitation, the risk level can drop by 40 percent); malnutrition, anaemia or retarded growth, blindness, schistosomiasis, and cholera and are very common disease of the slum areas in Delhi, Mathura and Agra. The formation of public sanitation facilities especially in the slum areas situated near either sides of the river is the best solution to prevent further deterioration.

\subsubsection{Formation of Electric Crematorium and Create Awareness}

Cremation in Yamuna River and on its banks is also one of the reasons of river water pollution. Every day approximately 100 to 150 cremations are performed, most on wood pyres that do not completely consume the body. Along with the remains of these traditional funerals there are thousand more who cannot afford cremation and whose bodies are simply thrown into the Yamuna. Further the carcasses of thousands of dead cattle, which are scared to Hindus go into the river each year. The absence of adequate cremation facilities are contributing to large number of partially unbrunt corpses floating down the Yamuna.

Formation of electric cremation is the only solution of these problems. Muslims and Christians according to their rituals buried the body in the graveyard, whereas, Hindus and Sikhs burn up the cadaver and in the case of children's death body is surged into river. Both central and state government should accelerate it affords to guide, aware and convince people to use electric cremation for the antim sanskara (last rites) instead of wood. It's not only environment friendly but also least expensive.

\subsection{Formation of Holy Bathing Ponds}

In India people (Hindus) bathe in rivers due to religious convictions and beliefs and dump holy materials and related materials along with domestic solid waste in rivers. River Yamuna is among one of the holiest rivers in India and people frequently take mass bath in the river. Water quality is severely affected by mass bathing. Deterioration of river water quality may injure health of the people taking the dip and also the population downstream which use the river as a source of water for drinking and bathing purposes.

This problem can be solved by the formation of holy bathing ponds, near the ghats filled with river water along with artificial ground water recharge techniques. This will not only prevent river pollution but also recharge the groundwater resources.

\section{Afforestation}

Afforestation plays an important role in reducing the soil erosion and agricultural runoff. Afforestation along the either sides of Yamuna river banks would help in controlling the agricultural runoff, which is composed of fertilizers and pesticides. Further afforestation along the Yamuna River can also reduce the rise in river water temperature by preventing the direct exposure of river water with sunlight. This will also oxygenate the river water.

\section{Canal Formation}

Majority of the rural and some urban areas do not have the sewer systems in Delhi, Agra, Mathura and Etawah districts. Therefore the sewerage wastes and other domestic wastes flow directly to the Yamuna River through the open drains. Such wastes not only pollute the river but also pollute the surface and groundwater resources. This should be ban at any cost and a barrier between the river and cities/towns should be formed. Canals should be formed parallel to the river for carrying all the towns domestic and sewerage waste to 7 to $10 \mathrm{~km}$ downstream of the town or city and dumped to the river after treatment. This will not only prevent the Yamuna pollution but also help in solving the drinking water problems in Delhi, Mathura and Agra.

\section{Legislation and Fines}

Now it's become necessary to form strict rules and regulations and ensure their 100 percent implementation to control the escalating pollution in Yamuna River. Monitoring at the major pollution sites of the river should be started immediately. Dumping of domestic wastes and other polluting materials in river should be banned and fine and imprisonment of 6 months to 1 year should be imposed based on the self purifying abilities and waste assimilation capacities of a river, the effluent standards 
should be worked out separately for each of the various polluters [11].

\section{Awareness among the People}

Prevention of Yamuna river pollution cannot be achieved without people's participation. Therefore it's important to create awareness among the people regarding the way river pollution is occurring and its related consequences. People should be taught various means to be adopted to reduce the increasing pollution levels in the river. In Delhi, state government has formed 10 feet high wire barricades along all Yamuna bridge under the Yamuna Action Plan I with signboard messages to prevent people from tossing things into the Yamuna. Despite that almost everyday people throw flowers and religious materials in the river, which creates pollution. Help of different volunteer organizations and NGO's should be taken to launch campaign and create awareness. Print media and electronic media can play a major role in creating awareness and urging people not to throw garbage and other pollutants in rivers.

\section{Discussion and Conclusions}

Yamuna which acts as the life line for the majority of the cities like Yamuna Nagar (Haryana), Panipat, Sonipat, Delhi, Noida, Faridabad, Mathura and Agra plays a major role in polluting the river. Yamuna river flow is restricted through several barrages such as Tajewala barrage, Wazirabad Barrage, Okhla Barrage, Gokul barrage etc. These barrages are directly or indirectly affecting the river water quality and aquatic ecosystem. Sludges which contain inorganic, organic and other toxic matters usually get deposited at the upstream of the barrages and their sudden release in the downstream of the river water increases pollution level so high that led to the mass death of fishes especially Delhi and Eutriphicated segment frequently.

Yamuna river enters Delhi near the Palla village $15 \mathrm{~km}$ upstream of Wazirabad barrage, which acts as a reservoir for Delhi. Delhi generates approximately 2871 MLD of sewage, against an installed sewage treatment capacity of 1,478 MLD. Thus, about 1,393 MLD of untreated and a significant amount of partially treated sewage enter the river every day [12]. The Delhi sewage system can be blamed for it and steps should be taken from not putting the industrial waste into the river as most of the industries are on the banks of Yamuna. In Delhi river water is black and it hardly flows. Now it's become imperative to maximize the use of the existing treatment facilities and ensure the reuse of treated effluents. All waste, legal and illegal, sewered and unsewered must be trapped and treated and not mixed with untreated sewage. Centralized sewage treatment plants cannot be considered as good because the cost of transporting waste to the treatment facility and transporting treated effluent back to the point of reuse makes them too expensive to run. Therefore, treatment facilities need to be constructed close to the source of sewage generation. Catchment area delineation is also an important component of water quality management. In order to reduce pollutant loadings at an outfall, it is necessary to examine and improve water use practices in the areas where pollutants originate. Further the raw sewage must be treated before it is discharged into the river stream.

Large agricultural fields, of Uttaranchal, Haryana, Uttar Pradesh, and Madhya Pradesh significantly contribute to river pollution. If river catchment area is protected from the chemical contamination the river pollution related with irrigation can be minimized. This can only be done by switching to organic or biological farming methods and curtailing the use of pesticides and fertilizers.

Several water treatment technologies prevailing in West are very expensive and country like India cannot afford it. Besides, that the conventional water treatment processes, based on chemical coagulation and filtration or biological slow sand filtration, have little capacity to remove water-soluble pesticides. Therefore emphasis should be given to the easily feasible and economically feasible techniques capable of removing or minimizing the pesticides content from the water.

The quality restoration of any river, especially of the Yamuna at different locations, is a very complex and interdisciplinary endeavor. Yamuna River pollution cannot be minimized merely by diverting the routes of different drains carrying wastewaters and/or establishing sewage treatment plants. The required strategy for pollution control should not only be a multi-line approach but also be fool proof. The various sources of pollution in the Yamuna river and possible strategies to restore this ailing river to its pristine status must be thoroughly examined and effective and enduring solutions established and implemented.

\section{Acknowledgements}

I thank all the faculty members of the Civil Engineering Department, of Institute of Technology and Management (ITM) for providing working facilities and also for continuous encouragement.

\section{References}

[1] Central Water Commission, "Yamuna Basin Organization," 2009. http://www.cwc.nic.in/regional/delhi/welcome.html

[2] Hindu, "Delhi reduces Yamuna to a sewage drain," New Delhi, 2002. http://www.hinduonnet.com/thehindu/2002 /06/25/stories/2002062506380400.htm 
[3] D. S. Bhargava, "Most rapid BOD Assimilation in Ganga and Yamuna Rivers," Journal of Environmental Engineering, American Society of Civil Engineers, Vol. 109, No. 1, 1983, pp. 174-188.

[4] D. S. Bhargava, "Water Quality Variations and Control Technology of Yamuna River," Environmental Pollution, Series A, Ecological and Biological, Vol. 37, No. 4, 1985, pp. 355-376.

[5] D. S. Bhargava, "Revival of Mathura's Ailing Yamuna River," The Environmentalist, Vol. 26, No. 2, June 2006, pp. 111-122.

[6] "Yamuna Action Plan," 1993. http://yap.nic.in/about-yap. asp

[7] P. Verma, "The Mystery of Large-Scale Fish Fatalities in the Yamuna near Agra and the Conflicting Official Theories," Down to Earth, Vol. 12, 15 July 2002.
[8] Central Pollution Control Board, "Water Quality status of Yamuna River," New Delhi, April 2000. http://www. cpcb.nic.in

[9] B. Sengupta, "Water Quality Status of Yamuna River (1999-2005), Assessment and Development of River Basin Series: ADSORBS/41/2006-07," Central Pollution Control Board, Delhi, November 2006. http://www.cpcb. nic.in.

[10] "Yamuna Action Plan," 2003. http://www.wwfenvis.nic. in/pdf/yam.pdf

[11] D. S. Bhargava, "Technology for Rationally Setting Effluent Standards for Water Pollution Administration," Journal of Environmental Engineering Division, Institution of Engineers, Vol. 66, No. 1, 1985, pp. 12-15.

[12] "Delhi the biggest Culprite," Down to Earth, Vol. 5, No. 19970228, 1997. 